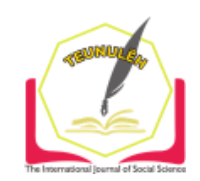

Jurnal Ilmiah Teunuleh

The International Journal of Social Sciences

Vol. 1, Issue. 2, Dec 2020

E-ISSN: 2746-4393

\title{
ANALYSIS OF SOCIAL COMPETENCY CHARACTER PLANTING IN CURRICULUM 2013 IN ELEMENTARY SCHOOL STUDENTS AT SDN 060870 MEDAN TIMUR SUBDISTRICT IN MEDAN CITY
}

\author{
Novani Maryam Rambe ${ }^{1}$ \\ Deny Setiawan ${ }^{2}$ \\ Siman ${ }^{3}$ \\ ${ }^{123}$ State University of Medan, Indonesia
}

\begin{abstract}
This study aims to study social competency character growers in elementary school 060870 East Medan, analyzing how the planting of social competency characters is influential in elementary school 060870 East Medan. This research uses a qualitative approach with descriptive analysis. The data analyzed were interviews with teachers, students, principals of SDN 060870, observations, and documentation. The results showed that: the planting of social competencies in the 2013 curriculum was carried out well. There are 2 aspects seen in the character of social competence, namely; first, interaction behavior, which has 4 characteristics contained therein; second, communication behavior which has 3 characteristics contained therein. Therefore, it is concluded that the planting of the character of social competence in SDN 060870 is carried out properly and in accordance with the required categories.
\end{abstract}

Keywords: Character planting, social competence, interaction behavior and communication behavior

\section{A. Introduction}

The development of science, technology, communication and the flow of globalization brings the impact of change in various aspects of life, including in the field of education. The presence of technology is like a double-edged sword. One side can help the community, on the other hand able to shift the ethics, norms, and culture maintained by previous generations. The fading of moral values that change with pragmatic values is a manifestation of the impact of globalization. This is because globalization teaches more effective achievement of goals where ethics is not one of the main things. 
Ethics and education are two interconnected points, a person who has an education will be seen from the way and lifestyle that shows the traits and words that are polite and polite. Education can take place well and successfully, if an educator understands and applies the concept of good nudity based on good ethics and morals (Tirtaraharja, 2005).

Law No. 20 of 2003 Article 3 of the National Education System states:

"National education serves to develop the ability and form dignified national character and civilization in order to educate the life of the nation, aiming to develop the potential of learners to become human beings who believe and fear God almighty, noble character, healthy, knowledgeable, capable, creative, independent, and become democratic and responsible citizens."

National education products are expected not only smart and smart but also characterful, moral, and characterful so that they can live in their day. Education is a conscious effort given or delivered by adults to immature children towards development towards maturity, a mature and independent person, both physical and spiritual (Abdullah Idi, 2011, p. 195). The same thing is also written in the philosophical purpose of national education, in general is as an effort to form students to have competence. In other words, the purpose of national education is to create Indonesian people who have knowledge, noble character, personality, and character.

With education, all the potentials of human beings can develop so that they become fully human. The ability to socialize, self-reliance, and self-control can be seen from the level of children's ability to connect with others and become productive members of social society. Pellegrini and Glickman definedsocial competence in children $a s^{\prime \prime}$ the degree to which children adapt to their school and home environment " which means social competence is a child's ability to adapt to the home environment as well as the school environment. (Pellegrini, Glickman, \& Carl, 1991)

Social competence is a person's ability to communicate, get along, cooperate, and give to others. Social competence as social intelligence or social intelligence in children to interact, communication, and adaptability to peers, family environment, school environment, and home environment. The development of skills as a learning process to conform to group norms, morals, and traditions. Melting into unity and social mutuality means the acquisition of the ability to behave in accordance with social guidance (Hurlock, 1978, p. 250). Social skills are another ability that the child must master, because the child will interact with others. Social skills refer to culturally expressed moral 
Analysis of Social Competency Character Planting in Curriculum 2013...

actions, such as sharing, helping someone in need, cooperating with others and expressing sympathy. Children's skills are a way of interacting both in behavior and in terms of communicating with others.

Public Elementary School 060870 is one of the schools in East Medan subdistrict that implements character planting with various activities carried out ruitn every day. These activities indirectly foster the social competence of the learners. Among them are literacy activities. Literacy activities are carried out daily in the classroom. Students read a book for 15 minutes before learning, after which they communicate it with their own sentences. The courage to appear in public is the potential of students who continue to be motivated to appear confident and not ashamed. Other activities such as: LISA movement (See Trash Take), 3S (Smile Greetings Greetings), Clean Friday (working together to clean up the school, classroom and surrounding environment) and Saturday Fun (gymnastics together, rallies and student creations), Scouts.

The above activities are one of the ways to instill confidence, responsibility, mutual help, discipline, manners, and care for the environment. This is the attraction of schools to have the largest number of students in east Medan subdistrict. The following is the table of admissions for students at SDN 060870 from 2015-2019 obtained from the Bid Education Office. Coordinator of East Medan Subdistrict of Medan City.

Table 1.1 Increase in Number of Students In $2015-2019$

\begin{tabular}{|c|c|c|}
\hline \multirow{2}{*}{ School } & School Year & $\begin{array}{c}\text { Number of } \\
\text { Students/Year }\end{array}$ \\
\hline \multirow{3}{*}{ SDN 060870 } & $2015-2016$ & 250 students \\
\cline { 2 - 3 } & $2016-2017$ & 300 students \\
\cline { 2 - 3 } & $2017-2018$ & 315 students \\
\cline { 2 - 3 } & $2018-2019$ & 478 students \\
\hline
\end{tabular}

Source: Documents of the Education Office of the Coordinator of the District of Medan Timur, Medan

Moving on from the facts above, I am interested in analyzing and reviewing the planting of social competency characters in elementary school students. This proposal is titled "Analysis of Social Competency Character Planting in Curriculum 2013 In Elementary School Students at SDN 060870 Medan Timur Subdistrict in Medan City".

\section{B. Method}

This research is a qualitative descriptive research that is research to understand the phenomenon experienced by the research subject holistically by describing it in the 
form of words in a special context that is natural by utilizing various natural methods as well.

Field data collection techniques use, interviews, and documentation called data triangulation. Data triangulation is a data collection technique that combinesvarious existing data collection techniques andsources (Sugiyono, 2013, p. 194). Data collection techniques carried out in the form of:

1. Obeservation

Observations will be made to observe the planting of social competence characters. Research using active participatory observations that is observation is carried out by the source but not completely complete.

2. Interviews

In this study the interview will be conducted unstructured, namely to find the problem more openly, where the interviewees are asked for opinions and ideas. Interviews will be conducted on some members of the school such as principals, teachers, and other research subjects to study information related to the planting of social competency characters.

3. Documentation

Documentation is carried out to strengthen data on the planting of social competency characters, in the form of documents, photos, videos and data in schools. Documentation is used as a data evidence that supports the observation of researchers in the field. However, the documentation presented is not in full but rather just a descriptive analysis of the findings.

\section{Data Analysis Techniques}

The implementation of data analysis is carried out at the time in the field and after the data is collected. Data analysis in the field is related to the importance of improving, both theoretical assumptions used and questions become the focus of research. The analysis after the data collected is done with the formulation of the discovery.

Activities in qualitative data analysis are carried out continuously until complete and the data is saturated (Miles \& Huberman, 1994, p. 10). Activities in this data analysis include data reduction, display data, conclusions: drawing/verification as follows: 
Analysis of Social Competency Character Planting in Curriculum 2013...

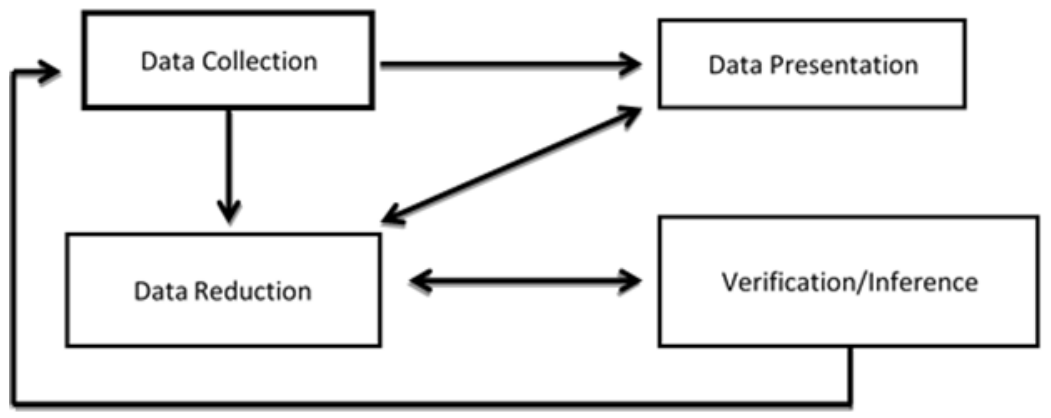

Miles and Huberman Interactive Data Analysis Model Chart

a. Data reduction means making summaries, choosing the main things, focusing on important things, looking for themes and patterns, and discarding what is considered unnecessary (Trianto, 2014, p. 287). After obtaining data from the field, both in the form of records in the field of observations, transcripts of interviews, and documentation in the form of video and photos.

b. Presentation of data (Data Display). The research was conducted in the form of a brief description or with text that is narrative and supported by field record data (comparison of interview transcripts and documentation).

Furthermore, the withdrawal of conclusions (data verification) which is the final stage as a form of data analysis in the research. The result is a paradigm based on discovery that is the answer to the problem formulation.

\section{Finding and Discussion}

\section{Research Findings of Planting Social Competency Character}

Character education aims to improve the quality of educational processes and results that lead to the formation of the character and noble character of learners as a whole, integrated and balanced, in accordance with the competency standards of graduates in each educational unit. Through character education, students are expected to be able to independently improve and use their knowledge, review and internalize and personalize the values of noble character and character so that it is manifested in daily behavior.

Character education in schools can simply be defined as, "understanding, care, and practice of virtue. Therefore, character education in schools refers to the process of planting values, in the form of understandings, procedures for caring for and living those values, and how a student has the opportunity to be able to practice these values for real. 
Novani Maryam Rambe, Deny Setiawan, Siman

Therefore, from the description that has been discussed about character education, it can be understood that the effort to apply character education is a process of planting character values that must be applied to learners, namely accuracy, discipline, habituation and creating a conducive atmosphere.

\section{a. Interaction Behavior}

Students should have good interaction with their teachers. This is seen when the teacher gives a briefing, the student listens and asks again about what he does not know. The interaction can be with the presence of manners and manners when asking and expressing opinionsthis happens not only during learning but when children are talking both during study hours and outside of studyhours. In line with that the teacher is an example for his students, the teacher must be able to be his friend first. To be a place of story for his students, a place to talk, and a place to complain. It doesn't become the opposite of a scary teacher or a cruel teacher.

This concludes that what is in the 2013 curriculum regarding character planting is seen from the interaction behavior that has been implemented by teachers. Where the teacher behaves like a friend to his students. This is done to facilitate the application of social competency character planting on interaction behavior.

There are several indicators of character planting on social competence towards interaction behavior including:

1) Friendly with students, educators, and school residents

Based on the results ofthe study tampak that children are very familiar with teachers, classmates, or other school residents. Basedon observations, discussions review interesting stories that they experience, where keseruan is seen from the movements of students who try to speakclearly by stretching the mask they wear. The same thing happens in the same class at different times. When a student delivers an assignment to school, they appear to beexchanging stories about activities during home study.

This event explained that the planting of character on social competence is carried out well. Where students rarely fight or fight with other friends. Looking familiar with his classmates even has a friend who is always invited to play together.

2) Rewarding an achievement. 
Analysis of Social Competency Character Planting in Curriculum 2013...

Rewarding students has a positive impact, teachers highly uphold the success of learning both academic and non-academic, thereby producing achievements for students. Reward also has an impact on theupsand downs and motivations for students to achieve goals in learning. The principal of SDN 060870, who has the initials ZP, explained that "Reward or reward is one of the strategies that I recommend to teachers to boost their learning interest. Not only interest in learning, but also as a stimulus not to be absent and not late to school. So the reward can encourage children to do good again with the rewards that have been promised as a form of habituation first."

Habituation to reward students is very motivating to do positive things such as, enterprising learning, coming on time and not skipping. As the expression of one of the teachers with the initial RH on August 31, 2020 said "In increasing the interest in learning students should give feedback in the form of praise or gestures that signify praise for student achievement even if the student is not appropriate. Not only that, rewarding gifts aims to motivate students to be more active in learning and students who are not excited can be more encouraged to be active in learning".

A student with the initials AP was happy when she received a gift from her teacher as an appreciation for always being on time when attending school. So this becomes a trigger for him to always get up quickly so as not to be late for school.

Rewarding has a huge impact on the planting of social competence character in the indicator of rewarding an achievement. It is proven that rewarding is able to increase students' motivation. The purpose of reward implementation is to monitor and control the order of learners, encourage students to learn and raise awareness of students to be good and quality, so that students are encouraged to excel more.

The reward given to students is not only in the form of goods but in the form of praise, applause, thumbs up and so on. With the reward can make students feel appreciated the results of their work so that students can be more enthusiastic in learning and improve their learning outcomes. The most valuable reward for students is a plus in appreciating their hard work. This concludes that the reward provided is able to provide motivation to encourage students to race to do everything, both school and homework. Everyone needs praise even elementary school students.

3) Maintain politeness and hospitality towards anyone 
Maintaining politeness is defined as mutual respect and respect for each other both to teachers and to other friends. From the observations described the politeness that occurs in the student is inseparable from the upbringing of a teacher. In line with the results of the interview with the principal with the initial ZP said that "The development of students' manners conducted by teachers include coaching in their speaking attitude, manners in deeds, and manners in dressing. Examples of attitudes fostered in polite language is when speaking should use polite words both when giving questions to teachers, discussing and when joking with students. That does not only apply to students, the teacher must also give good behavior because whatever the teacher does will certainly be imitated by the students. Therefore teachers should set a good example in speaking words and getting along".

The same behavior was also shown by some teachers at SDN 060870, such as trying to advice with polite and polite speech when they saw a student behaving badly. Here's also when you get used to shaking hands, being polite, and friendly while in the school area. In the hope that he can get used to being in his daily environment. It turns this refraction into a character, so that every meet wherever the children do not forget to shake hands. Even during these pandemic times the culture of greetings does not disappear.

A student when questioned said "From the first grade the teacher has taught greetings every time he enters the classroom and comes home from school. Also shake hands if you meet anywhere, and say hello to older people.

This indicates that manners are very important to be taught to learners. One of the coachings carried out by teachers is the development of politeness in language. This needs to be taught to students how to answer questions politely and how to speak in front of teachers politely. With this coaching, students will always say politely with anyone and anywhere.

4) Help maintain the cleanliness of the school environment

The cleanliness of the school is a shared obligation between the teacher, the student, and all the elements in it. As a form of awareness, cleanliness is an interaction behavior that must be cultivated early on. So that formed individuals who love the environment. So far the planting of social competence to interaction behaviors has worked very well. But generally, the cleanliness of the school is charged to the school guard. This is a poor example of the implementation of education, especially in 
schools. Because there will be a perception that they no longer need to clean the office and classrooms because there are already school guards who clean it. Finally make the perception of students negative to the cleanliness of the school environment.

In fact, almost all students know that cleanliness is a reflection of one's personality. Indipatience with the cleanliness of the school environment, especially the classroom, can slow down the effectiveness of learning and make the environment uncomfortable or unsightly. Similarly, concern for cleanliness can provide benefits, such as the effectiveness of learning that becomes smooth and the atmosphere of learning becomes comfortable. This needs to be considered as well as finding the best solution to suppress the lower concern for the cleanliness of the school environment that may be caused by certain factors such as environmental influences, and lack of a sense of responsibility to the environment. Regarding the hygiene activities at SDN 060870, the headmaster said that early on the students had become accustomed to healthy livingsuch as throwing garbage in their place, preparing garbage cans in every corner of the school, and sanctioning students who litter. This is done so that a clean culture can be established in the school environment and their homes, said a teacher at SDN 060870.

Similarly, a student with the initials PA said, "maintaining the cleanliness of the school must be ma'am. Because garbage cans are provided in every class. If littering is legal with the teacher. We also have to be clean and tidy, because every Friday the teacher will raid personal hygiene".

Based on this expression, it appears that students care about the cleanliness of their school environment by always maintaining cleanliness wherever they are. Cleanliness is also important for our health, because in a healthy body there is a strong soul. Likewise, the environment in our classrooms, the classes we study in. A clean school environment is one of the elements that must be existed, fostered and developed continuously so that in the ongoing education process achieves the expected results.

\section{b. Communication Behavior}

Communication is one of the axis in character education system because it can bridge all elements or sub systems involved in the system. The role of teachers in education, especially in learning activities is inseparable from the communication used in the delivery of learning materials. To be able to carry out learning activities or communication with learners, teachers or educators must understand the basic concepts of educational communication such as understanding the communication process, good 
communication techniques, forms of communication, understanding of the methods used in communicating, strategies in communicating and so on. In essence, a high understanding of the concept of communication will facilitate the learning process, character education, so that goals can be achieved effectively.

Good student communication occurs if there is coaching from a teacher to a student. Based on observations and interviews with the headmaster (initially ZP) said "The child will do a good deed if the school contains good elements. For example, in my students in grade $V$ they act well if I as a teacher do good deeds, whether behavior or communication. Good student communication occurs when the teacher gives direction to the student with good communication, the child will always imitate what he/she sees and then do it so that I as a teacher must do a good thing so that my students also do good things even though it does not have to be the same as what I do".

The phrase is reinforced from a conversation with a teacher (initially SW), saying "We always apply good behavior to all students in this school as habituation. Character planting must be done early in accordance with the school's mission. So, teachers should try to transmit such good attitudes, such as saying politely, saying hello to teachers, students and others".

The result of an interview with a student stated "Teachers always say speak the right language, do well and do good things. If we are one of the teachers always remind, for example if passing in front of the teacher must say excuse me, and if you meet the teacher should be reprimanded and experienced".

The role of educators in designing communication messages or materials is certainly not easy. Thus it takes the ability to make the right strategy. The message or material is selected based on a defined purpose. Not all facts or information can be used as material or message in character education. Character education material must be rigorously selected, analyzed its effectiveness, suitability to the specified objectives. Which material is suitable for achieving cognitive goals or knowledge of moral knowing, material which is suitable for achieving affective goals or feelings about moral feeling, as well as material suitable for achieving moral behavioral goals. Likewise, consideration of the value developed must have conformity with the selected material.

There are several factors in determining communication behavior in the planting of social competence characters including:

1) Communicate Politely 
Based on the information of the source, it is known that the language impression cannot be equated. Language impression is influenced by the relationship between culture and residential environment. Basically the words spoken by children are not always bad unless they are in a high emotional level so the language spoken will not be controlled.

A teacher with the initial $\mathrm{RH}$ argues that in principle children do not always say bad, bad words only come out when their emotional level is high, their procedures in conveying words are also quite good at their age, only that they still use language that is not standard in expressing opinions during learning.

This becomes the capital for students to always remember their teacher's message to always speak politely and kindly, and not to shout. Especially when they talk to older and younger people, whether their parents, brother, brother, or sister.

From observations and interviews, it is known that the planting of social competence character towards students' communication behavior on polite language indicators in communicating and speaking has been good according to their age. Where the school environment is a good place to live in fostering manners in speaking and culture to be skilled in speaking, expressing opinions, and discussing so that it has a positive impact on the development of student character.

\section{2) Get along effectively}

Getting along in this case is making good friends with each other, making friends not only with classmates, but educators or teachers can be made reliable friends for students when not in the study room. A RH teacher concludes, "every student has their own best friend, which is why it may be because his house is close or because his hobbies are the same and may be because he likes the same man (for them the friend is a friend who can make them laugh happily). In fact, it is not uncommon for them to become gang names for their kind of friendships such as the large number of female students, and it is not uncommon for them to exchange bracelets and even if there is a task they cooperate in tracking them. But the problem is if one of them does something wrong, surely one of the gangs thinks he's wrong, and that's how friends are at their age."

Based on the observations and interviews with the speakers, it is concluded that in terms of getting along almost all students get along well there are even some students who always talk to the teacher during the break. At this stage the social character of the students develops well because students get along effectively with each other. 
3) Have the skills to work together in groups

Based on interviews with teachers at SDN 060870, the skills of working together in groups have been well established. Even the recognition of longing for school, learning, playing together and meeting with friends illustrates that cooperation between students goes very well. Thisgemberian factor arises because teachers have previously applied and accustomed students to independent learning by forming learning groups, and not infrequently they are told to become peer tutors as the application of the 2013 curriculum.

The enthusiasm of students in receiving teacher instruction for group work is also very high in the period of learning from home. Proving that group learning is one need that can encourage students to learn in achieving learning goals in school. This way teachers will not find it difficult to develop learning strategies when learning is allowed face-to-face again.

\section{Discussion}

The success of the student's learning process is largely determined by the teacher's social competence. This is because the teacher is the leader of the learning. Teachers are learning leaders, facilitators, and also learning centers. Therefore, teachers must always develop their abilities. Teachers need to have professional standards by mastering materials and learning strategies and can motivate students to study vigorously.

The teacher is a very dominant and important figure in formal education. For students teachers are role models who become role models, even become inspirational figures. Therefore, teachers must have adequate competency behavior to develop students as a whole, in accordance with the objectives of education, namely developing the potential of students optimally. Competency standards are a breakthrough issued by the ministry of education and culture that seeks to give an overview of the things that must be owned by a teacher to improve the quality and quality of education in Indonesia by improving teacher professionalism.

Based on the observations and interviews, it is known that the character growers in the social competency category in the 2013 curriculum performed well although not all at the point of social competence were carried out perfectly, but it was concluded that 
Analysis of Social Competency Character Planting in Curriculum 2013...

the social character growers on social competencies had done well. The social competencies carried out are two, namely:

a. Interaction Behavior

Social interaction is one of the conditions for mental growth, if not fulfilled will inhibit the development of the soul, one of which is the development of self-concept. Therefore, social interaction is important for learners so that their development can grow to the maximum. The student's experience of social interaction will give the student a new outlook that can influence the concept of self. A pleasant experience, providing satisfaction that tends to evoke positive self-motivation for students.

Teachers whose social interactions instill a lot of good will surely be rewarded with kindness. On the contrary, teachers who always instill ugliness such as being rude, grumpy, rigid, and irritable will not get a harmonious relationship with their students. As a result the teacher becomes a less sympathetic figure in the eyes of students. Such a teacher will only appear as a "feared" figure, not "respected" and "respected". Thus, the advices and lessons delivered tend to be ignored by students. A good teacher is a teacher who bases his interactions with students on the values of love. Because only a relationship based on love will give birth to harmony.

According to Santoso (Santoso, 2010, p. 167), in the lives of individuals there is a spirit to imitate from each individual. This means that each individual simply relies on impersonation in his or her life. The imitation result of the process of social interaction is that each individual has a mild behavior that will cause mutual understanding and interest in each other. It is this mutual understanding that strengthens and facilitates ongoing social interactions between individuals.

Interaction behavior occurs according to what is experienced by students, the experience of what is seen and perceived will greatly affect the quality of interaction patterns. School age has not been able to determine what to model and what should not be modeled. At this stage the teacher acts as a wise player in doing all actions. In line with that Melchioriyusni (2018) in his journal explained that interactions occur due to the process of impersonation between adults and children who are considered immature, both the poor interaction patterns of children depending on what they see and what they hear.

Based on interaction behavior there are 4 categories in its application:

1) Befriend students, educators, and school residents 
In this category, teachers are able to position themselves as friends or friends of a student. Listen to what they're talking about, and see what they're doing. When the teacher becomes the student's best friend, the teacher can give teaching, as well as good deeds to educate the character of the student so that the character of the student can be formed perfectly.

2) Rewarding an achievement

Efforts to improve student learning achievement can not be separated from the role of a teacher who is the center of learning. Every media, method and model of learning used by teachers in teaching is very influential on students' learning outcomes, both cognitive, affective and psychomotor learning outcomes. Learning outcomes are changes in behavior that students get after experiencing learning activities. Teachers are always attentive to students' learning behavior, modification of students' behavior in learning by rewarding or punishment, as reinforcement of positive and negative, and application of individual learning principles to classical learning.

Appreciation is something that can motivate students to be better. Rewarding as an appreciation of the good that has been done will motivate other students to do good. Such as giving gifts to students who are never absent, giving praise in the form of words or attitudes, and so on.

3) Maintain politeness and hospitality towards anyone

Manners are an important element in daily social life, because by showing manners, a person can be appreciated and liked by his existence as a social being wherever he is. In the life of socializing among human beings, of course we have norms / ethics in making relationships with others. In this case manners can provide many benefits or influences both on yourself and others.

Manners means the rules of life arising from the association of a group of people in society and considered as the demands of daily association of the community. The character of manners is a character that everyone really needs to have. If a person does not have the character of manners, then he will be shunned by those around him. But, along with the development of the times and technology, the character of manners is fading. The cause of the fading of the character of manners is the influence of western culture. Many adults even follow the style of western cultural trends. So in this case it is necessary to instill the character of manners so that they can behave politely and say good manners to everyone. 
Based on expert opinions it is concluded that manners are a gentle nature that belongs to everyone who can be seen from the point of view of language and behavior in everyday life. Manners is a Javanese term that can be interpreted as the behavior of a person who upholds the values of respect, respect, and noble character. Manners can be considered an unwritten norm governing how we should behave or behave.

4) Help maintain the cleanliness of the school environment

Giving an example is better than explaining a theory. Teaching nudity by giving precision. A good teacher will set an example rather than just an instruction to the student. For example, in protecting the environment, teachers not only give directions about protecting the environment but also participate in doing so by citing the garbage in the schooly yard. By exemplifying this attitude students will be motivated to do the same.

In line with that Utami (Munandar, 2017) said that a clean environment is able to create effective learning conditions to support the process of teaching and learning activities. The cleanliness of the school environment needs to get more attention from the school because a healthy environment will provide positive values for students in doing learning.

\section{b. Communication Behavior}

Communication becomes part of the human routine. From the results of the study, $90 \%$ in 24 hours of human activity is communication. Logically, if the communication is already integrated in one's routine, it will automatically imply directly to the character of one another through habituation so that it becomes a habit and also has an indirect impact on others, whether in a fast or slow process depending on the intensity and effectiveness of communication that is intertwined. Communication becomes a system in the process of character education. That is, character education is influenced by the quality of communication that is intertwined. Effective communication has universal terms, conditions, principles and strategies so that its existence to date is significantly applied in character education.

Communication in education is a very important element of its position, even very large role in determining success. In the implementation of formal education (school education), it is clear that there is a very prominent role of communication. The teaching and learning process occurs mostly because of the communication process, both intrapersonal and interperspersed communication. The most important element in 
communication is not just what is written or done but how the message is conveyed to the recipient of the message. The main requirement in effective communication is a solid character built on strong integrity.

There are three categories on communication behavior, namely:

1) Communicate Politely

The determining factor of impression is everything that can affect the use of language to be polite or un polite. The determining factors of speech in verbal spoken language include aspects of intonation (the softness of intonation when a person speaks), aspects of speech tone (blessings with the emotional atmosphere of the speaker; official tone, joking tone, mocking tone, insinuation, and so on), word choice factor, and sentence order factor. While in verbal communication of writing, the determining factor of impression is the choice of words related to the value of taste, the length of sentence structure, expression, style of language, and so on.

Profanity in language is an urgent form of behavior for each individual in using language, so it must always be done when those people are ready to communicate. In reality, human behavior individually can be ascertained there are differences in using language, namely from the use of one language to compare with the other. One person uses language with manners even very polite, but there are also other individuals speaking in no manners. The problem of language in communicating with others, whether officials, peers or indeed circles in general is good if always use polite language.

2) Get along effectively

A person should have flexibility in hanging out, otherwise his social interactions will become rigid and cause problems in society. Teachers become the center of observation and assessment of students, while in the community the teacher becomes the center of observation and assessment of the community itself.

Instilling character values in learners is done by habituation through various activities in the classroom that are carried out continuously and consistently at all times, so that learners will get used to doing good and right things that are ingrained in the student. Teaching how to get along well will provide a class atmosphere that tends to be calmer and more directed during learning.

3) Have The Skills to Work Together in a Group 
Cooperation is the actions of a group of individuals who have the same problems, goals and agreements, helping each other in solving problems to achieve goals. It takes a willingness to work together to get the job done. Teachers are required to have the skills to work with peers exchanging information in order to develop their skills and competencies. The increasing ability of teachers has an impact on increasing the spirit of learning and building students' confidence.

\section{Conclusion}

Based on the results of research conducted on the analysis of social competency character planting in the 2013 curriculum in elementary school students at SDN 060870 Kec. Medan Timur was carried out very well. Principals and teachers synergize to apply the planting of social competency character to the interaction behavior and communication behavior to students. Habituation to behavior that reflects social character continues to be fostered to all students especially grade $V$ students at SDN $060870 \mathrm{Kec}$. Medan Timur in the learning process both in the classroom and outside the classroom. Like saying polite, hanging out effectively, caring about the environment, being polite to anyone, being able to work in groups.

Indicators of social competence consist of 2 aspects, namely interaction behavior and communication behavior. Interaction behavior aims to bring learners closer between what they know to be good and behaving correctly to every form of action that reflects the value of understanding with real and concrete. This interaction behavior is wellbehaved, both between teachers and students and between students and students. So that the planting of character on aspects of interaction behavior is carried out well.

Communication behavior aims to shape students into individuals who have good character, good manners, get along well, and help each other, so that they can be prepared to become leaders in the future. This communication behavior is seen based on how the attitude of impression in speaking, respect with the teacher and good behavior while playing. This behavior is carried out well even though the results have not yet seen that students find it difficult to control good words when they are playing with their friends. 
Novani Maryam Rambe, Deny Setiawan, Siman

\section{Bibliography}

Abdullah Idi, H. (2011). Sosiologi Pendidikan: Individu, Masyarakat, dan Pendidikan. Jakarta: Rajawali Pers.

Arikunto, S. (2010). Prosedur Penelitian Penelitian Suatu Pendekatan Praktik. Jakarta: Rineka Cipta.

Boqdan, R., \& Biklen, S. (1992). Qualitative Research fo Education. Boston: MA: Allyn and Bacon.

Hurlock, B. E. (1978). Psikologi perkembangan. (Istiwidayanti, \& Soedjarwo, Trans.) Jakarta: Penerbit Erlangga.

Indonesia, P. R. (2005). Undang-Undang Republik Indonesia No. 19 Tahun 2005 Tentang Standar Pendidikan Nasional. Jakarta: Kementerian Hukum dan HAM RI.

Kemdikbud. (2012). Dokumen Kurikululm 2013. Jakarta: Kemdikbud.

Miles, M. B., \& Huberman, A. M. (1994). Qualitative Data: an expanded sourcebook. London: Sage Publication.

Moleong, L. (2010). Metodologi Penelitian Kualitatif. Bandung: Remaja Rosdakarya.

Munandar, S. C. (2017). Mengembangkan Bakat dan Kreatifitas Anak Sekolah, Petunjuk Bagi Guru dan Orang Tua. Jakarta: PT Gramedia.

Narwanti, S. (2011). Pendidikan Karakter. Yogyakarta: Familia.

Pellegrini, A. D., Glickman, \& Carl, D. (1991). Measuring Kindergartners' Social Competence. ERIC Digest.

Robert, E. S. (2011). Psikologi Pendidikan: Teori dan Praktik. Jakarta: Indeks.

Sugiyono. (2013). Metode Penelitian Pendidikan Pendekatan Kuantitatif, Kualitatif, dan $R \& D$. Bandung: Alfabeta.

Tirtaraharja, U. (2005). Pengantar Pendidikan. Jakarta: Rineka Cipta.

Trianto. (2014). Model Pembelajaran Terpadu: Konsep, Strategi, dan Implementasinya Dalam Kurikulum Tingkat Satuan Pendidikan (KTSP). Jakarta: Bumi Aksara. 